удк 004:687.5.01

DOI: 10.31866/2617-796X.4.1.2021.236943

\title{
Тимошенко Олена,
}

доктор економічних наук, доцент, професор кафедри фешн- і шоу-бізнесу, Київський національний університет культури і мистецтв, Київ, Україна etymoshenko@i.ua https://orcid.org/0000-0003-3820-1492

\section{Мисюк Анна,}

студентка 4-го курсу, кафредра фешн- і шоу-бізнесу,

Київський національний університет культури і мистецтв,

Київ, Україна

maylandguid@gmail.com

https://orcid.org/0000-0003-2541-1175

\section{Коцюбівська Катерина,}

кандидат технічних наук, доцент,

в. о. завідувача кафедри комп'ютерних наук,

Київський національний університет культури і мистецтв,

Київ, Україна

kateryna@knukim.edu.ua

https://orcid.org/0000-0002-3987-9871

\section{Хрущ Світлана,}

асистент, заступник декана факультету дистанційного навчання,

Київський національний університет культури і мистецтв,

Київ, Україна

miksa@ukr.net

https://orcid.org/0000-0001-9349-7762

\section{ОСОБЛИВОСТІ ПРОЦЕСІВ ДИДЖИТАЛІЗАЦІї У ФЕШН-ІНДУСТРІЇ}

Мета дослідження - розкрити особливості процесів диджиталізації у сфері індустрії моди, визначити основні напрями розвитку диджитал-технологій та їх безпосередній вплив на фешн-середовище.

Методи дослідження. Вибір методів дослідження зумовлений метою статті, зокрема застосовано системний підхід до опрацювання робіт з історії моди, диджитал-технологій, трендів майбутнього в креативних індустріях, а також аналіз вже наявних змін у середовищі фешн-індустрії.

\footnotetext{
(C) Тимошенко О. В.

(c) Мисюк А. О.

(c) Коцюбівська К. І.

(C) Хрущ С. С.
} 
Наукова новизна. Порушено питання проблематики розвитку індустрії моди під впливом цифрових технологій.

Висновки. Отже, для управління фешн-брендами майбутнього потрібно не тільки ефективно керувати командою та орієнтуватися на прибуток, а й бути гнучкими, соціально відповідальними та швидко реагувати на нові диджитал-тренди та використовувати їх у своїй роботі. Так епоха диджиталізації змушує наш світ переходити на новий рівень розвитку. Фешн-індустрія, як одна з найбільш гнучких та прибуткових сфер, має якнайшвидше переймати нові диджитал-технології та застосовувати сучасні й дієві методи управління, які будуть доцільними та ефективними.

Ключові слова: диджиталізація; диджитал-маркетинг; віртуальна реальність; цифрова трансформація; індустрія моди; фешн-індустрія; мода; тренди; диджитал-епоха; креативні індустрії; культура; бізнес; ефективність.

Вступ. Розвиток соціокультурної сфери й індустрії моди зумовлює появу нових технологій, методів та інструментів управління, а разом з цим відкриває і горизонт можливостей для розвитку професійних умінь. Однак фахівці, які не обізнані в сучасних тенденціях економіки, освіти, управління та комунікацій, можуть зазнати краху на професійному поприщі через нестачу знань, практичних навичок і дієвих інструментів тієї галузі, в якій вони працюють. Диджитал-трансформація активно впливає на наше суспільство та на всі його сфери. Будь-яким компаніям і проєктам потрібно бути готовими до змін, які приносить нова диджитал-епоха, та не тільки виготовляти продукти (послуги), що відповідають сучасним трендам, а й змінювати своє внутрішнє середовище, адже методи, які працювали раніше, зараз уже працюють менш ефективно.

Мета статті - розкрити особливості процесів диджиталізації у сфері індустрії моди, визначити основні напрями розвитку диджитал-технологій та їх безпосередній вплив на фешн-середовище.

Виклад проблеми. Диджиталізація, диджитал-маркетинг, віртуальна реальність, цифрова трансформація - ще декілька років назад дещо фантастичні слова наразі в усіх на вустах та є одними з передових орієнтирів для успішного функціонування бізнесу, вірогідно, у будь-якій сфері. Термін “диджиталізація» означає цифрову трансформацію суспільства та економічних процесів, перехід від індустріальних підходів до епохи творчості та глобальності, які дають змогу продуктивніше функціонувати, розвиватися та відображаються у вигляді цифрових технологій i digital-інновацій у сучасному світі, а саме бізнесі, економіці, маркетингу, рекламі та багатьох інших галузях.

Індустрія моди - це галузь з виробництва новинок у сферах одягу, взуття, аксесуарів тощо, але самим виробництвом індустрія моди не вичерпується: вона несе за собою певні ціннісні орієнтири та смаки - впливає на суспільство (Мельник, 2015). Мода завжди зводила виробника зі споживачем, але завдяки індустріалізації вона перетворилася з елітарної, недоступної для загалу сфери, у щось буденне й ходове. Речі стали доступніші, а люди одягаються краще. В основі фешн-середовища лежить своєрідна система прийняття та передачі інформації, яка розповсюджується між людьми - переходить від одного прошарку суспільства до іншого, від однієї групи до іншої. Наприклад, сусідка купує модний халат 
і розповідає про це своїй подрузі, а та у свою чергу ще десятьом приятелькам. Чи звичайний хлопець дивиться фільм з Джонні Деппом і мріє про такий самий костюм, а потім йде й шукає його аналог. Колись було саме так, проте зараз $є$ набагато ефективніші та потужніші технології, які охоплюють не просто цільову аудиторію, а майже всіх жителів нашої планети. 3 цього випливає, що мода являє собою пласт інформаційних і комунікаційних технологій, які допомагають її суб'єктам бути попереду інших.

Мода - це своєрідна сукупна форма поведінки широких мас. Вона зазвичай виникає та проявляється масово, а саме під тиском популярних у соціумі настроїв, мінливих уподобань і смаків. Саме слово «мода» походить від латинського терміну «modus», яке означає міру, стандарт, звичай, настрій, образ, вид. Проте в XVII ст. французькі та італійські мислителі починають вживати цей термін для характеристики соціальних і психологічних стихійних поведінок людей у суспільстві, які відображаються в їх виборі зачісок, одягу, декору, прикрас, засобів догляду, подарунків, хобі, фільмів, музики, манери поведінки й інших смакових уподобань. Відповідно до цього тлумачення більшість людей обирає той самий одяг чи ту саму їжу, схиляючись не стільки до своїх відчуттів і вподобань, а до тих, що зараз панують у суспільстві. Отже, соціально-психологічний вплив моди на людей $є$ настільки сильним, що більшість навіть не усвідомлює того, хто вони є, які в них уподобання та інтереси, тому що це все сформовано під впливом феномену моди.

Наявні підходи до розвитку індустрії моди можуть здаватися дещо застарілими та вже не такими ефективними. Десятиліттями різним компаніям і брендам було достатньо виробляти якісні продукти та вказувати відносну пристойну ціну, а для збільшення пізнаваності - купувати рекламу в глянцевому виданні чи на телебаченні. Зараз це вже не працює таким чином.

За останні роки (орієнтовно з 2000 року) різні цифрові технології (мобільний інтернет, штучний інтелект, соціальні мережі) мали кардинальний розвиток і здійснили перехід від експертного застосування до повсякденного життя людей. Цифрова трансформація базується на технологіях. Якщо, наприклад, державні органи частіше приймають лише паперові документи та працюють з файлами, то ринки змінюються набагато швидше. Індустрія моди та медіаіндустрія були першими, хто відчув наслідки цифрової трансформації, а наразі практично всі галузі промисловості зазнають впливу диджиталізації.

Маркетинг та продажі зазнають значних змін, зумовлених зміною інформаційної поведінки клієнтів. За останні роки з'явилося безліч нових дисциплін, таких як оптимізація пошукових систем та вхідний маркетинг. Вони продовжують набирати високу цінність, тому що так звана подорож клієнта, тобто індивідуальний досвід клієнтів на шляху від пошуку інформації до придбання та використання товару чи послуги, стає центральним компонентом маркетингу та продажів.

Цифрова трансформація також впливає на продажі. Так звані «холодні дзвінки» стають усе менш важливими. Генерація потенційних клієнтів усе частіше відбувається на власній домашній сторінці компанії. Вхідний маркетинг і продажі зростають разом. В управлінні та менеджменті digital відіграє не менший вплив. Так, у найближчі роки найважливішим завданням управління будь-якою компані- 
єю буде керування цифровою трансформацією на всіх рівнях компаній: процеси та процедури, організаційні структури, розвиток цифрового маркетингу та продажів, пропозиції цифрових послуг і цифрові бізнес-моделі. Корпоративна й інноваційна стратегія буде доповнена цифровою стратегією.

Для того щоб збагнути, який вплив матиме диджиталізація в майбутньому, потрібно почати з того, що цифрові зміни - це радикальні зміни в економіці та суспільстві, що відбувалися протягом майже 50 років та відбуваються й досі.

Основною та незмінною метою індустрії моди є прибуток. Однак ні про який розвиток, а тим паче високий прибуток, не може йти мови, якщо немає сучасного, ефективного та продуманого управління. Ті методи й інструменти управління, які працювали раніше, наразі мають зовсім низькі результати, адже наш світ за останні декілька років кардинально змінився. Диджиталізація бізнесу - це вагома перевага та набір ефективних функцій, які допомагають просувати, збагачувати та підтримувати якісне існування бізнесу в сучасному світі, а особливо - у сфері індустрії моди.

Розглянемо основні переваги та функції застосування digital-технологій у соціокультурній діяльності:

- економія часу: автоматизація виробництва та різних механічних процесів дає змогу будь-якій компанії заощаджувати найцінніший капітал - час; коректне та продумане використання соціальних мереж бренду одягу, наявність чат-ботів, сайтів, швидкої доставки, автоматизованої розсилки - це все допомагає зменшити щоденну затрату фізичних та інтелектуальних ресурсів і, як наслідок, збільшити ефективність роботи;

- підвищення продуктивності: з пункту першого випливає те, що автоматизація внутрішніх процесів компанії допомагає не тільки заощаджувати час, а й підвищувати продуктивність роботи працівників, адже тепер їм не потрібно затрачати декілька годин на суто механічні речі, а можна зосередити свою увагу на більш нагальних і масштабних цілях компанії;

- оптимізація та покращення комунікацій: за допомогою офіційних сайтів, сторінок у соціальних мережах та умілого застосування СММ-просування в будьякої компанії значно покращується спілкування з її аудиторією та партнерським середовищем, тому що її більше не потрібно довго й нудно шукати та чекати багато часу на відповідь - тепер усе доступніше, прозоріше та зручніше; до того ж між клієнтами та брендом вибудовуються міцні взаємини, а це також доволі вагомий капітал будь-якого бізнесу (The Nielsen Company, 2020);

- можливості крос-продажів (upsell-продажів): використання digital-технологій дає змогу брендам виходити на якісно новий рівень обслуговування клієнтів. За допомогою цифрового маркетингу заохочувати аудиторію до покупок більшої кількості продукції стає набагато простіше;

- конкурентні можливості: використання digital-технологій також дарує компанії низку конкурентних переваг, які вигідно відмежують ії від інших і підкреслять усю ії унікальність. За допомогою поліпшення клієнтського досвіду, автоматизації та оптимізації робочого процесу, можливості крос-продажів, поліпшення комунікації, наявності глобальної СММ-стратегії та міцних близьких відносин з цільовою 
аудиторією компанія цілком логічно отримує більшу кількість переваг, зокрема стійкого внутрішнього середовища, високої продуктивності та ефективності праці, пристойного доходу, популярності та впізнаваного іміджу.

Традиційно в індустрії моди виділяють професії дизайнера, стиліста, фотографа, журналіста, баєра та продавця. Але сьогодні це лише частина професій індустрії моди, яка зазнала значних змін за останні роки. Ці зміни призвели до зміщення пріоритетів у діяльності компаній і зміни ролей, на які вони наймають працівників (The Nielsen Company, 2020).

Попереду шість нових фешн-професій, які стануть ще більш важливими в майбутньому. Інженер 3D-друку займе значну частку роботи в індустрії моди, адже впровадження 3D-друку дасть змогу зробити виробництво швидшим, простішим і дешевшим. Очікуємо, що в майбутньому обороти світової індустрії 3D-друку зростуть до 21 млрд доларів (Грицай, 2002).

Ще одна професія - психолог з роботи зі споживачами, адже в сучасному суспільстві одяг задовольняє не так практичні утилітарні потреби, як соціальні й психологічні, тому це призводить до виникнення нової групи фахівців - психологів моди - тих, хто застосовує психологічні теорії, щоб розуміти мотиви вибору одягу й емоції, які викликає його використання. Аналітик даних буде стежити за споживачем і поглиблено вивчати його для прогнозування трендів до персоналізації рекомендацій на індивідуальному рівні, а розробник нових матеріалів уже доволі популярний, наприклад Nike та Louis Vuitton не шкодують коштів на розробку інноваційних технологій для створення нового покоління матеріалів, які покращують споживчі властивості, продуктивність виробництва й екологічність продукції. Ще одна професія - екоексперт. Його функцією є впровадження екологічно безпечних методів виробництва. І остання професія - персональний стиліст, популярність якого зросла з появою цифрового маркетингу та дала змогу йому проникнути в майже всі прошарки сучасного суспільства.

Управління брендом - це комплексний регулярний менеджмент побудови та поліпшення бренду, який здійснюється на всіх етапах його розвитку. Традиційно управлінням і розвитком того чи іншого проєкту в індустрії моди займається бренд-менеджер. До його основних завдань входить розвиток і просування бренду, розробка стратегій, робота з працівниками компанії для підвищення ії результативності, планування довготривалих цілей та контроль усіх процесів (Гупта, 2019). Проте у 2021 році цього традиційного набору управління вкрай замало. Завдяки глобалізації брендів та масовому виробництву фешн-продукції товари стають примітивними й одноманітними. Щоб їх продавати, виробники використовують маркетинг, брендинг, рекламу, які за невмілого впровадження можуть спричинити негативні наслідки замість очікуваних якісних результатів.

Бренд майбутнього повинен перерозподіляти ресурси та розв'язувати актуальні проблеми. Так він зможе знадобитися людині в розкритті самої себе. Уже сьогодні $€$ такі фірми, купуючи товари яких, ви не просто витрачаєте гроші, а допомагаєте чиїйсь творчості, сприяєте благодійності чи реалізації певного соціального проєкту. Акцент в економіці вже зараз зміщається з матеріального виробництва на виробництво інформації. 
Посилаючись на дослідження Purpose2020 і Nielsen, можна виділити такі тренди в управлінні брендами. Перше місце у бренд-менеджменті майбутнього займає голос бренду - його соціальна позиція, непохитний імідж, високі цінності та погляди: таким чином споживач розуміє з ким він має справу (Purpose 2020 Kantar, 2020). Соціальна відповідальність - не менш важливий чинник, який повинні брати сучасні управлінці до уваги: у фешн-рекламах усе частіше використовують соціальні образи людей з обмеженими можливостями, похилого віку, національні та релігійні меншини. До того ж 53 \% споживачів очікують соціальної відповідальності від компанії.

Доповнена та віртуальні реальності зацікавили багатьох ще у 2019 році, а в майбутньому цей тренд міцно займе панівні позиції не тільки в індустрії мод, а й у медицині, освіті, економіці та ін. У 2021 році, поки ситуація у світі залишається нестабільною, компаніям доведеться скорочувати свої витрати й адаптуватися до нових умов ведення бізнесу. У зв'язку з цим виникає ще один тренд управління - оптимізація витрат та структур: соціальні мережі, віддалена робота, онлайн-навчання - усі цифрові методи тут надто доречні (Гупта, 2019).

Ще однією провідною бізнес-тенденцією у 2021 році стане автоматизація. Наприклад, це наявність у компаній чат-ботів, які автоматично приймають запити щодо обслуговування клієнтів.

Як відомо, фешн-індустрія - одна чи з не найбільш небезпечних і неекологічних індустрій у світі. Тому в розрізі управління модними брендами буде доцільно використовувати орієнтир на стійкість, а саме - сталий розвиток (Purpose 2020 Kantar, 2020). У 2021 році фешн-бренди мають переосмислити свою діяльність, вплив на навколишнє середовище, використання продукції, адже, як показують дослідження, це буде відігравати вагому роль для споживачів.

Віртуальний одяг - більше не фантастичні історії чи мрії. Передові дизайнери та IT-працівники створюють його вже зараз, а головне - активно продають його. У 2019 році скандинавський бренд продав цифрову сукню за 9500 тисяч доларів. Тут потрібно зробити уточнення: сукня наявна лише онлайн, одягнути ії̈ можна тільки онлайн і ніде більше. Виникає питання, чи є такий феномен тільки в економічно розвинутих країнах, але це все також відбувається і в інших куточках світу. Наприклад, в Україні.

У 2020 році український бренд FINCH випустив першу в Україні колекцію цифрового одягу. Світшоти й футболка з капсули FFFACE x FINCH мають функцію віртуальної 3D-анімації, яка спрацьовує в камері смартфона, коли ії̈ наводять на принт футболки або світшота через Інстаграм. Ціна виробів коливається в межах 1600-2500 грн. Один виріб з капсульної колекції FFFACE x FINCH може мати кілька віртуальних ефектів, або, інакше кажучи, людина може створити декілька стильних фото в абсолютно різних образах за допомогою однієї футболки. Переваги очевидні: бренди не руйнують екологію нещадним виробництвом, а споживачі замість однієї речі отримують одразу декілька

До того ж технологія виготовлення віртуального одягу значно простіша, швидша та безпечніша для довкілля, ніж реального. Під час виготовлення таких виробів дизайнери не обмежені практично нічим: їм доступний більш широкий асор- 
тимент фактур, кольорів і форм, тому вони можуть створювати яскраві, зухвалі та футуристичні образи. Віртуальні речі максимально екологічні: їх виробництво, зберігання та утилізація не завдає шкоди навколишньому середовищу.

«Доповнену реальність в ритейлі» (augmented reality, або AR) витлумачують як віртуальне середовище, яке накладається на реальний світ для поліпшення сприйняття інформації про навколишню дійсність. Системи доповненої реальності зазвичай складаються з двох компонентів:

1) апаратні засоби - спеціалізовані дисплеї, окуляри, шоломи та портативні пристрої (в основному смартфони);

2) програмне забезпечення - хмарні сервіси та бібліотеки для розробників (SDK).

AR найбільш часто використовує камеру смартфона для накладення цифрового контенту на фізичний світ. Тобто користувач наводить камеру смартфона на реальний виріб або інтер'єр і на екрані бачить те, чого немає. У цьому відмінність доповненої реальності від віртуальної, де користувачеві не потрібно послуговуватися смартфоном.

У доповненій реальності можливо розміщувати:

- тривимірні моделі;

- анімовані сцени, що складаються з декількох тривимірних моделей;

- інтерактивні тривимірні моделі;

- інтерактивні 2D-сцени;

- інтерактивні анімовані 2D-сцени;

- двомірні зображення (ілюстрації, фотографії);

- відеофайли, накладені на вертикальну або горизонтальну площину.

Віртуальний одяг - це речі, які створюють у тривимірному вигляді за допомогою спеціальних програм. Щоб одягнути digital-наряд на людину, дизайнер бере його фото в одязі, що обтягує, а поверх накладає нову цифрову річ. Цей тренд зародився пару років тому, а пандемія та прискорений перехід в онлайн підігріли його розвиток. Віртуальний одяг, на відміну від реального, наявний тільки в онлайн-просторі, у фізичному світі його немає. Однак на фото чи відео він має максимально природний вигляд завдяки 3D-технології та графічному дизайну. Диджитал-речі також повторюють положення тіла, мають згини, заломи й тіні.

Глобальний вплив диджиталізації на індустрії моди не тільки відкриває нові можливості для компаній, а й закриває старі двері, підтверджуючи той факт, що ті бренди, які не зможуть адаптуватися до змін, скоріше за все загинуть. 28 вересня 2020 року Велика Британія відмовилася від виготовлення та продажу натурального хутра. Це рішення уряд прийняв після того, як кілька великих брендів, таких як Gucci, Burberry, Tom Ford, Versace, Prada, відмовилися від використання хутра (Вумек та Джонс, 2018). Можливо, поява digital-технологій на майданчику модної індустрії - це свого роду відповідь на жахливий стан екології, де не останню роль відіграло нищівне модне виробництво та бездумне споживання.

Жоден виробничий процес в індустрії моди не є сприятливим для навколишнього середовища, і навіть ті компанії, що називають себе «екодружелюбними», беруть до уваги лише задоволення мінливих потреб споживачів. Адже в кінцево- 
му підсумку виробництво від 20 до 35 \% мікропластику, який опиняється у Світовому океані, на совісті модної індустрії, а вуглецевий слід, який продукують фабрики, перевищує той, що створюють усі авіарейси та торговельні центри у світі (Вумек та Джонс, 2018).

Віртуальний одяг має низку переваг:

1. Підвищує конкурентоспроможність бренду.

2. Допомагає бренду вийти на новий ринок і захопити значно більший сегмент споживачів.

3. Робить бізнес більш гнучким, пристосованим до різких змін і менш залежним від зовнішніх чинників.

4. Не потребує нищівного виробництва, яке вбиває екологію, та не засмічує нашу планету умовно після того, як виходить з моди.

Покоління Z, майбутнє світового споживання, уже зараз починає впливати на ринки. Згідно з дослідженнями, це покоління переймається через стан довкілля значно більше, ніж їхні батьки та бабусі. Наприклад, серед американців покоління Z майже кожен третій готовий заплатити більше, щоб нанести менше шкоди природі, а ще вони готові споживати менше, щоб заощадити ресурси.

До того ж роблять покупки вони обдумано - лише якщо товар відповідний та екологічний. Це викликає своєрідну "моду на екологічність», де бренди та виробництво змагаються, використовуючи не що інше, як digital-технології. Наприклад, Burberry створюють екоколекції: одяг та аксесуари з пластику, відходів і перероблених матеріалів; Converse малюють мурали на стінах великих міст, які поглинають забруднення і очищають повітря. Варто зазначити, що використання диджитал-трендів в управлінні бізнесу має низку переваг - це економія часу, підвищення продуктивності, розширення ринків збуту, постачальників, посередників і споживачів, оптимізація та поліпшення комунікацій і конкуренті можливості.

Мода - це одна зі сфер, яку охоплює культура, тому модна індустрія, як і соціокультурна індустрія, $є$ феноменом, що не стоїть на місці, а розвивається, міняє форми, породжує нові шляхи та відкриває нові джерела. До появи інтернету модна галузь охоплювала тільки телебачення (різноманітні реаліті-шоу, канали про моду чи конкурси), а наразі ця індустрія успішно функціонує в наших смартфонах і не тільки у вигляді розважального контенту, а і як справжній бізнес. Сьогодні навіть не потрібно заходити на сайти брендів одягу, щоб щось придбати, адже багато магазинів цілком успішно працюють у соціальних мережах.

Сьогодні абсолютно ясно, що віртуальна мода - це не тимчасове явище, не наслідок глобального карантину, не ще один тренд і не просто забавка, яка стала ненадовго популярною серед молоді. Можливо, усі ці явища і прискорили ії розвиток, проте потрібно усвідомити, що межі між реальним і віртуальним розмилися остаточно. Від моменту, коли одне замінить інше, світ поки що дуже далекий, та й цілком зрозуміло, що віртуальний світ навряд чи зможе повністю перевершити реальність, але співіснувати ці два виміри можуть і, що найголовніше, дарувати нам, людству, нові можливості. Сьогодні ми вже досягнули того моменту, коли обидва світи можуть існувати й існують у симбіозі. 
3 приходом диджиталізації також варто окреслити й зміни в спілкуванні та відносинах між споживачем і брендом. В епоху інтернету брендам необхідно привернути увагу та розповісти свої історії клієнтам, викликаючи їхню прихильність. Для цього важливо правильно сегментувати свої аудиторії та надсилати їм правильні повідомлення: у потрібний час подавати потрібне повідомлення зацікавленій людині. Людей сьогодні нелегко зацікавити, а відлякати просто. Прозорість і етика бізнесу важливі як ніколи. Багато фешн-брендів зазнали осуду за те, що вони не пропонують гідних умов праці чи зарплат, ще більше - за плагіат, культурну апропріацію чи зневагу до інших культур. Але найбільше нетерпимі споживачі до расизму чи будь-якої соціальної дискримінації.

Зміст модної індустрії полягає в ії безупинному розвитку, адже за своєю природою мода як феномен виникає та виявляється масово, під впливом загальновизнаних у соціумі настроїв, уподобань і смаків. Індустрія моди - це не просто бізнес-середовище, а й свого роду культурний чинник, який відіграє соціально-психологічний вплив на людство. Мода часто відіграє вирішальну роль у спілкуванні між людьми, у рівні культурного розвитку країни. Віртуальні технології у свою чергу є провідним чинником розвитку фешн-індустрії, адже диджитал-трансформації не тільки дають змогу підвищити конкурентоспроможність товарів, розширити ринки збуту, знаходити нових постачальників, посередників і споживачів, а й сформувати нове економічно стійке, свідоме та гнучке середовище, яке буде активно функціонувати й відігравати соціально відповідальну роль.

На сьогодні для того щоб створити якісний і прибутковий продукт на теренах ринку моди, необхідно застосовувати високі технології. Диджитал-трансформації допоможуть швидше й ефективніше підвищити рентабельність проєкту, а ще й забезпечать соціально відповідальну позицію брендам, адже модна індустрія $€$ однією з чи не найнебезпечніших для екології. Сучасні споживачі (покоління Z) купують речі не так для реального життя, як для свого віртуального світу, тому у 2021 році доцільно буде переглянути питання виробництва й задуматися щодо створення віртуального одягу, який наявний лише онлайн. До того ж не можна оминути й ті можливості, що відкриває епоха диджитал-трансформацій, і те, як вона спрощує діяльність як маленьких брендів, так і міжнародних компаній.

Висновки. Отже, для управління фешн-брендами майбутнього потрібно не тільки ефективно керувати командою та орієнтуватися на прибуток, а й бути гнучкими, соціально відповідальними та швидко реагувати на нові диджитал-тренди й використовувати їх у своїй роботі. Так епоха диджиталізації змушує наш світ переходити на новий рівень розвитку. Фешн-індустрія, як одна з найбільш гнучких і прибуткових сфер, має якнайшвидше переймати нові диджитал-технології та застосовувати сучасні дієві методи управління, які будуть доцільними й ефективними. 


\section{спИСОК ПОСИЛАНь}

Вумек, Д. та Джонс, Д., 2018. Ощадливе виробництво. Київ: Каравела.

Грицай, Е.В., 2002. Мода в контексте глобализации. Актуальні проблеми духовності, 4, c.235-240.

Гупта, С., 2019. Цифрова стратегія. Посібник із переосмислення бізнесу. Переклад: І. Ковалишена. Київ: КМ-Букс.

Мельник, М.Т., 2015. Індустрія моди. Київ: Ліра-К.

Purpose 2020 - Kantar. [online] Avialable at: <https://www.kantar.com/Inspiration/Brands/ The-Journey-Towards-Purpose-Led-Growth> [Accessed 20 May 2021].

The Nielsen Company. [online] Avialable at: <https://www.nielsen.com/us/en/about-us/ global-responsibility-and-sustainability/> [Accessed 25 May 2021].

\section{REFERENCES}

Gritcai, E.V., 2002. Moda v kontekste globalizatcii [Fashion in the context of globalization]. Aktualni problemy dukhovnosti, 4, pp.235-240.

Hupta, S., 2019. Tsyfrova stratehiia. Posibnyk iz pereosmyslennia biznesu [Digital strategy. A guide to rethinking business]. Translated: I. Kovalishen. Kyiv: KM-Buks.

Melnyk, M.T., 2015. Industriia mody [Fashion industry]. Kyiv: Lira-K.

Purpose 2020 - Kantar. [online] Avialable at: <https://www.kantar.com/Inspiration/Brands/ The-Journey-Towards-Purpose-Led-Growth> [Accessed 20 May 2021].

The Nielsen Company. [online] Avialable at: <https://www.nielsen.com/us/en/about-us/ global-responsibility-and-sustainability/> [Accessed 25 May 2021].

Vumek, D. and Dzhons, D., 2018. Oshchadlyve vyrobnytstvo [Lean production]. Kyiv: Karavela. 
UDC 004:687.5.01

\section{Tymoshenko Olena,}

Doctor of Economics, Associate Professor,

Professor of Fashion and Show Business Department,

Kyiv National University of Culture and Arts,

Kyiv, Ukraine

etymoshenko@i.ua

https://orcid.org/0000-0003-3820-1492

\section{Mysiuk Anna,}

4th-year Student, Department of Fashion and Show Business,

Kyiv National University of Culture and Arts,

Kyiv, Ukraine

maylandguid@gmail.com

https://orcid.org/0000-0003-2541-1175

\section{Kotsiubivska Kateryna,}

PhD in Technical Sciences, Head of Computer Science Department,

Kyiv National University of Culture and Arts,

Kyiv, Ukraine

kateryna@knukim.edu.ua

https://orcid.org/0000-0002-3987-9871

\section{Khrushch Svitlana,}

Assistent, Deputy Dean of the Faculty of Distance Learning,

Kyiv National University of Culture and Arts,

Kyiv, Ukraine

miksa@ukr.net

https://orcid.org/0000-0001-9349-7762

\section{FEATURES OF DIGITALIZATION PROCESSES IN FASHION INDUSTRY}

The purpose of the research is to reveal the features of digitalization processes in the field of the fashion industry, to determine the main directions of digital technologies development and their direct impact on the fashion environment.

Research methodology. The choice of research methods is determined by the purpose of the research, in particular, a systematic approach to the study of fashion history, digital technologies, future trends in the creative industry, as well as analysis of existing changes in the fashion industry.

Scientific novelty. The issue of the fashion industry development under the influence of digital technologies is raised.

Conclusions. Therefore, to manage the "fashion brands of the future", you need not only to effectively manage your team and focus on profit but also to be flexible, socially responsible and quickly respond to new digital trends and use them in your work. Thus, the era of digitalization forces our world to move to a new level of development. The fashion industry, as one of the 
most flexible and profitable areas, must adopt new digital technologies as quickly as possible and apply modern and effective management methods that will be expedient and effective.

Keywords: Digitalization; digital marketing; virtual reality; digital transformation; fashion industry; fashion industry; fashion; trends; digital age; creative industries; culture; business; efficiency.

\section{удк 004:687.5.01}

\section{Тимошенко Елена,}

доктор экономических наук, дочент, профессор кафедры фэшн- и шоу-бизнеса, Киевский национальный университет культуры и искусств, Киев, Украина etymoshenko@i.ua https://orcid.org/0000-0003-3820-1492

\section{Мисюк Анна,}

студентка 4-го курса, кафедра фэшн- и шоу-бизнеса, Киевский национальный университет культуры и искусств, Киев, Украина maylandguid@gmail.com https://orcid.org/0000-0003-2541-1175

\section{Кочюбивская Екатерина,}

кандидат технических наук, дочент, и. о. зав. кафедрой компьютерных наук, Киевский национальный университет культуры и искусств, Киев, Украина kateryna@knukim.edu.ua https://orcid.org/0000-0002-3987-9871

\section{Хрущ, Светлана,}

ассистент, заместитель декана факультета дистанционного обучения, Киевский национальный университет культуры и искусств, Киев, Украина miksa@ukr.net https://orcid.org/0000-0001-9349-7762

\section{ОСОБЕННОСТИ ПРОЦЕССОВ ДИДЖИТАЛИЗАЦИИ В ФЭШН-ИНДУСТРИИ}

Цель исследования - раскрыть особенности процессов диджитализации в сфере индустрии моды, определить основные направления развития диджитал-технологий и их непосредственное влияние на фэшн-среду.

Методы исследования. Выбор методов исследования обусловлен целью статьи, в частности применен системный подход к обработке работ по истории моды, диджи- 
тал-технологий, трендов будущего в креативных индустриях, а также анализ уже имеющихся изменений в среде фэшн-индустрии.

Научная новизна. Затронуты вопросы проблематики развития индустрии моды под влиянием цифровых технологий.

Выводы. Итак, для управления фэшн-брендами будущего нужно не только эффективно управлять командой и ориентироваться на прибыль, но и быть гибкими, социально ответственными и быстро реагировать на новые диджитал-тренды и использовать их в своей работе. Таким образом эпоха диджитализации заставляет наш мир переходить на новый уровень развития. Фэшн-индустрия, как одна из самых гибких и прибыльных сфер, должна как можно быстрее перенимать новые диджитал-технологии и применять современные и действенные методы управления, которые будут целесообразными и эффективными.

Ключевые слова: диджитализация; диджитал-маркетинг; виртуальная реальность; цифровая трансформация; индустрия моды; фэшн-индустрия; мода; тренды; диджитал-эпоха; креативные индустрии; культура; бизнес; эффективность.

28.05.2021 